\title{
OWNER-MANAGER CHARACTERISTICS INFLUENCE ON THE SMES INNOVATION ORIENTATION OF SMEs: A LITERATURE EXPLORATION
}

\author{
Ahmad Aminu Daneji ${ }^{1}$ \\ Faculty of Science, Technology, Engineering and Mathematics, \\ International University of Malaya-Wales, Kuala Lumpur, Malaysia. \\ (Email: shp180004@student.iumw.edu.my) \\ Kamran Shavarebi ${ }^{2}$ \\ Faculty of Science, Technology, Engineering and Mathematics, \\ International University of Malaya-Wales, Kuala Lumpur, Malaysia. \\ (Email: kamran56@iumw.edu.my) \\ Jeffrey Boon Hui Yap ${ }^{3}$ \\ Lee Kong Chian Faculty of Engineering and Science, \\ Universiti Tunku Abdul Rahman, Selangor, Malaysia. \\ (Email: boonhui78@yahoo.com)
}

Received date: 08-09-2019

Revised date: 10-09-2019

Accepted date: $18-12-2019$

Published date: 18-12-2019

To cite this document: Daneji, A. A., Shavarebi, K., \& Boon, H. Y. J. (2019). Owner-Manager Characteristics Influence on The SMEs Innovation Orientation of SMEs: A Literature Exploration. International Journal of Innovation and Industrial Revolution, 1(2), 01-11.

DOI: $10.35631 /$ IJIREV.12001

Abstract: The firm's involvement in innovation became a necessary attribute for firms to remain competitive and successful. However, innovation is still considered a hallmark of large firms only. The literature on SME's involvement in innovation is scant and needs further exploration regarding the innovation process in the SME firms. This paper aims to hint the gap of knowledge related to the association between the owner-manager characteristics and innovation orientation at the SMEs. A review of relevant literature was exhausted for the achievement of the study objective. The findings of the study highlight that to fully explore the innovation process at the SME level, there is a need to divide the innovation concept into innovation creation and innovation adoption as two discrete concepts effected by the ownermanager personal characteristics. Literature hints at these two conceptualizations of the innovation among SMEs, but empirical examination is non-existence. Therefore, this work recommends future research endeavors to empirically examining the direction and strength of the relationship between owner-manager characteristics and SME's innovation performance in terms of creation and adoption. Moreover, literature and policy direction can be drawn from the respective research activities. 
Keywords: Owner-Manager Characteristics, Innovation Orientation, Innovation, SMEs

\section{Introduction}

Business organisations are looking for competitive advantage, and innovation creation or adoption at a firm-level provides an essential competitive advantage to the firm (Akinwale, Adepoju \& Olomu, 2017). Innovation is the key to the progress of the business firm and critical to remain competitive. Creation of innovation and innovation adoption are the hallmarks of SMEs' growth and performance (Abdu \& Jibir, 2017; Baregheh, Rowley \& Sambrook, 2009). The firm's attitude for innovation and capacity to utilise innovation in product development, manufacturing, and services design enables the firm to achieve a competitive advantage and growth (Bigliardi, 2013). Innovation in large organisations remains the focus of past research as their resources for research and development $(\mathrm{R} \& \mathrm{D})$ and risk-taking capacity is much higher than SMEs (Blanchard, 2017). Moreover, the innovations from large organisations are easily visible and create tremendous market impact.

SMEs are facing different internal and external challenges in terms of their innovation outlook to remain competitive (Antonioli \& Della Toree, 2015; Mohammed \& Abimiku, 2015). However, most of the SMEs lack the ability and capability to engage in innovation-related activities (Boyer \& Blazy, 2014; Hu, Horng \& Sun, 2009). Also, it is worthwhile to keep in mind that SMEs owners and managers are sole decision-makers of their firms, and SMEs lacking in innovation adoption, in general, is described as the owner's or manager's inability to adopt the innovation at the firm level (Aminu \& Shariff, 2015; Danosh, Oteng \& Frimpong, 2017). The literature discussing the innovation in SMEs' is scant, and very few studies have explored the role of owner-manager personal attributes in the SME's innovation performance. Innovation is categorised into innovation creation and innovation adoption at the firm level (AbuJarad \& Yusof, 2010; Escriba-Esteve \& Montoro-Sanchez, 2012). The current work explores the recent literature on the role of owner-manager personal attributes on the SME innovation creation and adoption performance. Moreover, it highlights the need to explore the phenomenon empirically in future studies.

The next section reviews the relevant literature among SMEs concerning innovation orientation and personal factors of the owner-manager on the SME innovation performance. After taking stock of the relevant literature, the research gap was highlighted with a proposed future research endeavour to fully explore the owner-manager personality effects on the SME innovation performance. These future research undertakings can fully expose the SME's innovation undertaking to make the SME more inclined towards innovation creation or adoption.

\section{Literature Review}

SMEs are playing a significant role in the economic development of most nations (Abdu \& Jibir, 2018). Developed and developing economies rely significantly on their SMEs' sector performance and growth (Anderson, Potocnik \& Zhou, 2014). Moreover, SMEs also come forward as the leading supplier of employment and helps to reduce the impact of unemployment as well as poverty (Akinwale et al., 2017). SMEs' performance is highly associated with the adoption of innovation and entrepreneurial aptitude of the SME's owners/managers enabling 
them to engage in innovation at product or service level and facilitating the general economic conditions of the nation (Hosseini \& Narayanan, 2014; Martinez-Roman \& Romero, 2017).

\section{SMEs and Innovation}

SMEs' performance is a significant research area and scholars have studied many antecedents of SME performance. Innovation has been viewed as a critical antecedent of SME performance and growth (Mateu \& March-Chorda, 2016). Engaging in innovation is a critical factor for SME's success and gaining a competitive advantage (Bigliardi, 2013). However, innovation is complex and dynamic by nature and has various meanings posited by different scholars (Lai, Yusof \& Kamal, 2016; Martinez-Roman \& Romero, 2017). Innovation became a necessary element of the firm's business strategy as it provides new business opportunities with the development of new products/services or improving the existing product/processes to remain competitive (Naranjo-Valencia, Jimenez-Jimenez \& Sanz-Valle, 2011; Olughor, 2015). The highly competitive business environment provides critical input for the firm's level innovation initiatives in terms of improving efficiency in firm performance at any level (Mutterlein \& Kunz, 2017). Innovation efforts are the essential success factor for the firm to engage in continuous development and growth activities (Wadhwa, McCormick \& Musteen, 2017). The literature on SME's involvement in continuous development and innovation activities is growing (Yesil \& Dogan, 2019). However, the SME's performance in terms of the innovation orientation and innovation at the firm's level derived by the owner-manager characteristics is scant.

\section{Innovation Orientation and Innovation Orientation}

Innovation as a concept is a sophisticated phenomenon and described by many scholars in different contexts (Fagerberg \& Srholec, 2008; Rogers, 2004). Innovation is described as a new or significantly improved product or process that is new to the market or for the organisation (Rogers \& Rogers, 1998). The newly introduced products or processes based on new technology, knowledge, or material and results to significant savings in terms of financial or non-monetary advantage for the firm (Nguyen, Pham, Nguyen \& Nguyen, 2008). The conceptualisation of what constitutes "new" or "significantly improved" remains the point of contention among scholars. Therefore, more exploration is needed to make a clear distinction between innovation creation and innovation adoption.

Innovation orientation refers to the creation or adoption of a new product and process that is new for the adoptee firm or market (Yusof et al., 2017). Literature delineates two distinct meanings of the innovation orientation, i.e., innovation creation and innovation adoption. Recent literature clarifies the discrete characteristics, organisational culture, drivers, and strategies for innovation creation and innovation adoption (Subrahmanya, 2015; Wadhwa et al., 2017). Table 1 highlights the recent previous studies regarding innovation orientation. 
Table 1: Previous studies on Innovation Orientation

\begin{tabular}{|c|c|c|c|c|c|}
\hline $\mathbf{S} / \mathbf{N}$ & Authors & Location & Industry & $\begin{array}{l}\text { Level of } \\
\text { Analysis }\end{array}$ & Variables \\
\hline 1 & $\begin{array}{l}\text { Dansoh et al. } \\
\text { (2017) }\end{array}$ & Ghana & $\begin{array}{l}\text { Construction } \\
\text { SMEs }\end{array}$ & Firm Level & $\begin{array}{l}\text { Internal Firm } \\
\text { Characteristics }\end{array}$ \\
\hline 2 & $\begin{array}{l}\text { Yusof et al. } \\
\text { (2017) }\end{array}$ & Malaysia & $\begin{array}{l}\text { Construction } \\
\text { SMEs }\end{array}$ & $\begin{array}{l}\text { Individual } \\
\text { Level }\end{array}$ & $\begin{array}{l}\text { Entrepreneur`s effort, } \\
\text { Risk attitude and R\&D } \\
\text { spending }\end{array}$ \\
\hline 3 & $\begin{array}{l}\text { Lai et al. } \\
\text { (2016) }\end{array}$ & Malaysia & $\begin{array}{l}\text { Construction } \\
\text { SMEs }\end{array}$ & Firm level & \\
\hline 4 & $\begin{array}{l}\text { Kamal et al. } \\
\text { (2016) }\end{array}$ & Malaysia & $\begin{array}{l}\text { Construction } \\
\text { SMEs }\end{array}$ & Firm level & Firm Characteristics \\
\hline 5 & $\begin{array}{l}\text { Hosseini et al. } \\
\text { (2014) }\end{array}$ & Malaysia & $\begin{array}{l}\text { Manufacturing } \\
\text { SMEs }\end{array}$ & Multi-Level & $\begin{array}{l}\text { Export orientation, } \\
\text { collaboration in } R \& D \text {, } \\
\text { technical support, export } \\
\text { supply, } R \& D \text { incentives } \\
\text { and support from mother } \\
\text { firm }\end{array}$ \\
\hline 6 & $\begin{array}{l}\text { Magadley and } \\
\text { Birdi, (2012) }\end{array}$ & UK & Multi Industry & $\begin{array}{l}\text { Individual, } \\
\text { Team and } \\
\text { Firm level }\end{array}$ & $\begin{array}{l}\text { Domain expertise and } \\
\text { Self efficacy, Team } \\
\text { Support and Safety, } \\
\text { Organisational Support } \\
\text { and flexibility }\end{array}$ \\
\hline 7 & $\begin{array}{l}\text { Escriba'- }^{\prime} \\
\text { Esteve and } \\
\text { Montoro- } \\
\text { Sa'nchez, } \\
(2012)\end{array}$ & Spain & $\begin{array}{l}\text { Manufacturing } \\
\text { SMEs }\end{array}$ & $\begin{array}{l}\text { Individual } \\
\text { level }\end{array}$ & $\begin{array}{l}\text { Managerial Intrinsic and } \\
\text { Extrinsic values }\end{array}$ \\
\hline 8 & $\begin{array}{l}\text { Naranjo- } \\
\text { Valencia et al. } \\
\text { (2011) }\end{array}$ & Spain & $\begin{array}{l}\text { Manufacturing } \\
\text { SMEs }\end{array}$ & Firm level & Organisational Culture \\
\hline 9 & $\begin{array}{l}\text { Abujarad and } \\
\text { Yusof, (2010) }\end{array}$ & & Literature & Matrix & \\
\hline 10 & $\begin{array}{l}\text { Pérez-Luño et } \\
\text { al. (2010) }\end{array}$ & Spain & $\begin{array}{l}\text { Manufacturing } \\
\text { and Service } \\
\text { SMEs }\end{array}$ & $\begin{array}{l}\text { Individual } \\
\text { level }\end{array}$ & $\begin{array}{l}\text { Entrepreneurial } \\
\text { Orientation and } \\
\text { Environment Dynamism }\end{array}$ \\
\hline 11 & $\begin{array}{l}\text { Robson et al. } \\
\text { (2008) }\end{array}$ & Ghana & $\begin{array}{l}\text { SMEs } \\
\text { Entrepreneurs }\end{array}$ & Multi-level & $\begin{array}{l}\text { Firm Export, } \\
\text { Educational level and } \\
\text { Firm size }\end{array}$ \\
\hline 12 & $\begin{array}{l}\text { Damanpour } \\
\text { and } \\
\text { Wischnevsky, } \\
(2006)\end{array}$ & U.S & Literature & Firm level & $\begin{array}{l}\text { Firm Characteristics, } \\
\text { Innovation } \\
\text { Characteristics }\end{array}$ \\
\hline
\end{tabular}


Studies reported in Table 1 describe the conceptualisation of innovation orientation at the individual level, organisational level, and at multiple levels. At the individual level, entrepreneurial orientation comprises of individual pro-activeness and risk-taking combined with the firm-level environmental drive for the innovation at two discrete levels of "new to the world' as innovation creation and 'new to the firm' as innovation adoption (Custodio, Ferreria \& Matos, 2017; Dansoh et al., 2017). Perez-Luno et al. (2010) postulate that entrepreneurial orientation is a substantial predictor of innovation creation. Moreover, managerial antecedents also significantly envisage firm-level innovation and creativity (Farace \& Mazzotta, 2015). However, managerial idealization and creativity harness the climate that enables employee innovation and adoption inclinations (Fitjar \& Rodriguez-Pose, 2013). Yousaf et al. (2017) identified that factors such as pioneer's efforts, risk-taking, and firm R\&D spending are the key ingredients of the Malaysian construction firms in innovation orientation. However, innovation adoption is associated with imitating others, playing safe and having reduced R\&D spending are the key attributes of the innovation-adoption oriented firms (Bucktowar, Kocak \& Padachi, 2015; Daksa, Yismaw, Lemessa \& Hundie, 2018).

The studies that investigated the innovation orientation at a firm-level highlight organisationallevel factors as the primary source of initiating innovation (Beyer, Czarnitzki \& Kraft, 2012). Kamal et al. (2016) explore the Malaysian construction firm's characteristics and innovation orientation and describes the construction firm size and business scale as the significant features of the innovation orientation at the firm level. Damanpour and Wischnevsky (2006) suggest that the organisational feature of size and age, innovation characteristics, and measurement of innovation enables one to distinguish between construction firms that innovate or adopt innovation. Dansoh et al. (2017) investigates the Ghanaian small construction firms and reported 12 conditions for innovation creation and innovation adoption among the firms. The internal firm factors of culture and availability of resources are the significant firm-level dimensions that influence innovation creation and innovation adoption (Laguir \& Den Besten, 2016). Moreover, Naranjo-Valencia et al. (2011) described organisational culture as a determining factor to distinguish firms that create innovation or adopt.

Another segment of the studies analysed the factors at three levels, i.e., individual, group, and firm levels influencing innovation orientation. Mixed-method research strategy was adopted by Magadley and Birdi (2012) to investigate the innovation orientation and reported that the individual-level factors are more significant in predicting the idea generation and idea implementation in the firms than the group or firm-level factors. Nevertheless, Hosseini and Narayanan (2014) classified the firm's level innovation orientation as adopters, adapters, and creators to examine the effects of the different factors on the firm innovation activities. Reportedly, small and medium-sized firms based their innovation orientation on the factors of export orientation, R\&D incentives, technical support, R\&D collaboration, export supply, and support from parent firm for innovation creation, adaption, and adoption (Martinez-Roman \& Romero, 2017). The recent literature significantly discussed the innovation orientation at the individual level, group level, and firm-level factors, but the studies did not discuss the role of owner/manager characteristics on the firm's innovation orientation (Perez-Luno et al., 2011; Rietzchel \& Zacher, 2015). 


\section{Owner-Manager Characteristics}

SMEs are distinctly associated with the attribute of being individually owned and managed by one owner or a small team of managers (Olughor, 2015). SMEs became profoundly influenced by the owner/manager as decision-making is exclusively on them (Mohammed \& Abimiku, 2015). Few studies explored the owner/manager and top management team characteristics as the prompting factors on SME innovation performance (Quazi \& Talukder, 2011). Studies examined certain personal factors of the SME owner or managers like education level, demographics, and attitudinal factors influence on SME innovation and SMEs performance (Aminu \& Shariff, 2015; Subrahmanya, 2015; Wadha et al., 2017). However, these studies were unable to differentiate between the different innovation orientation (innovation creation and innovation adoption) among SMEs. Moreover, innovation orientation needs to be explored further to unearth the manager's factors that influence it (Yusof \& Abidin, 2011). Categorising the innovation into two types will enable scholars to fully disclose the necessary strategies to improve innovation performance in SMEs (Martinez-Ros \& Orfila-Sintes, 2012).

This section mainly discussed the relevant previous literature that explored the effect of the owner-manager characteristics on SMEs innovation performance in terms of innovation creation or innovation adoption. Table 2 summarises the previous studies reviewed for this research work. However, most studies have not adequately explored the association among the owner-manager characteristics with a particular type of orientation (adoption or creation) among the SMEs.

Table 2: Previous Studies on Owner-Manager Characteristics and Innovation

\begin{tabular}{|c|c|c|}
\hline $\mathbf{S} / \mathbf{N}$ & $\begin{array}{l}\text { Owner-Manager } \\
\text { Characteristics }\end{array}$ & Authors \\
\hline 1 & Age & $\begin{array}{l}\text { Laguir \& Besten (2016); Rietzchel \& Zacher (2015); Boyer \& } \\
\text { Blazy (2013) }\end{array}$ \\
\hline 2 & Gender & $\begin{array}{l}\text { Laguir \& Besten (2016); Ruiz-Jimenez \& Fuentes-Fuentes } \\
\text { (2015); Boyer \& Blazy (2013); Kasseeah (2013) }\end{array}$ \\
\hline 3 & $\begin{array}{l}\text { Level of } \\
\text { education }\end{array}$ & $\begin{array}{l}\text { Martinez-Roman \& Romero (2016); Quazi \& Talukder (2011); } \\
\text { Farace \& Mazzotta (2015); Kasseeah (2013) }\end{array}$ \\
\hline 4 & Experience & $\begin{array}{l}\text { Martinez-Roman \& Romero (2016); Laguir \& Besten (2016); } \\
\text { Mateu \& March-Chorda (2016); Boyer \& Blazy (2013) }\end{array}$ \\
\hline 5 & $\begin{array}{l}\text { Risk-taking } \\
\text { attitude }\end{array}$ & $\begin{array}{l}\text { Mutterlein \& Kunz (2017); Blanchard (2017); Martinez-Roman } \\
\text { \& Romero (2016); Beyer et al (2012) }\end{array}$ \\
\hline 6 & Innovativeness & Mutterlein \& Kunz (2017); Blachard (2017) \\
\hline 7 & Proactiveness & Mutterlein \& Kunz (2017); Blachard (2017) \\
\hline 8 & $\begin{array}{l}\text { Awareness of } \\
\text { innovation }\end{array}$ & Martinez-Roman \& Romero (2016) \\
\hline 9 & Training & $\begin{array}{l}\text { Antonioli \& Torre (2015); Farace \& Mazzotta (2015); Martinez- } \\
\text { Ros \& Orfila-Sintes (2012); Quazi \& Talukder (2011) }\end{array}$ \\
\hline 10 & Personal networks & $\begin{array}{l}\text { Yesil \& Dogan (2019); Wadhwa et al (2017); Bucktower } \text { et al } \\
\text { (2015); Farace \& Mazzotta (2015); Beckett \& Chapman (2014); } \\
\text { Fitjar et al (2013) }\end{array}$ \\
\hline 11 & Leadership style & Martinez-Roman \& Romero (2016); Ayranci, (2011) \\
\hline
\end{tabular}




$12 \begin{array}{ll}\begin{array}{l}\text { Managerial skills } \\ \text { and competency }\end{array} & \begin{array}{l}\text { Custodio } \text { et al (2017); Ruiz-Jimenez \& Fuentes-Fuentes (2015); } \\ \text { Chen } \text { et al (2015); Fitjar } \text { et al (2013); Martinez-Ros \& Orfila- }\end{array} \\ 13 & \begin{array}{l}\text { Attitudes (2012) } \\ \text { innovation }\end{array}\end{array}$

The owner-manager background influences his cognitive, behavioural, and attitudinal stance towards innovation activities (OECD, 2005; Sundbo, 1995). Few studies have explored the effects of the owner-manager educational level on the firm's level of innovation undertakings (Anderson, De Dreu \& Nijstad, 2004; Martinez-Roman \& Romero, 2017). A higher level of education significantly influences the owner-manager cognitive feature and enables him to pursue innovation opportunities (Farace \& Mazzotta, 2015; Hu et al., 2009). However, few studies reported the effect of owner-manager education on the firm's innovation orientation (Wolfe, 1994). Nevertheless, the owner-manager education level significantly influences the firm`s innovation orientation (Bhaskaran, 2006).

Furthermore, the professional experience of the owner-manager significantly influences the firm innovation performance (Baregheh et al., 2009; Martinez-Roman \& Romero, 2016). Additionally, the owner-manager leadership style also has a role in influencing innovation at the firm's level (Boyer et al., 2012; Martinez-Roman \& Romero, 2016). The gender of ownermanager also significantly influences the innovation activities of the firm. Studies signify that the male owner-managers are more innovation-oriented than the female owner-managers as females are associated with having low-risk orientation and are more conservative in their decision-making (Laguir \& Besten, 2016; Ruiz-Jimenez \& Fuentes-Fuentes, 2015). Also, owner-managers skills and capabilities gained over time influence innovation (Custodio et al., 2017). However, specific skills are required to gain a competitive advantage by engaging in innovation (Daksa et al., 2018). These skills are significantly technical for innovation creation or adoption at the firm level (Damanpour \& Wischnevsky, 2006; Wolfe, 1994).

Three dimensions of entrepreneurial orientation which are innovativeness; risk-taking and proactiveness also gain the attention of scholars to investigate their influence on innovation (Blachard, 2017; Mutter \& Kunz, 2018). Innovativeness deals with the willingness and intention to adopt or build innovative solutions. The risk-taking propensity of the ownermanager is associated with the willingness to take bold and risky decisions regarding innovation. A risk-taking attitude is highly associated with positive innovative performance (Mutterlein \& Kunz, 2018). Pro-activeness deals with the anticipation of the future and acting with eagerness to succeed with available resources at hand ahead of competitors (Blachard, 2017). Few studies explore the role of the social capital and owner-manager personal network as factors that affect innovation performance. Business, family, friends and supply chain partners are network resources that facilitate innovation (Bucktower et al., 2015; Farace \& Mazzotta, 2015).

\section{Conclusion}

SMEs provide significant economic development opportunities for countries. Innovation in SMEs is highly associated with their competitiveness. Literature exploring SMEs innovation performance is available and has established the importance of SME role in economic development. This paper aims to explore the relevant literature on innovation orientation 
among SMEs. The review of the relevant and recent literature highlights the research gap to explore the likely role of owner-manager characteristics and innovation orientation. A review of the literature suggests exploring the role of owner-manager characteristics on the influence of innovation orientation among SMEs. Exploring the role of SMEs owner-managers characteristics will help to identify new insights into the innovation orientation engaged by the SMEs. The owner-manager is playing a significant and critical role in running the SMEs and deciding the innovation orientation of the SMEs. Moreover, innovation needs to be viewed as two distinct activities of innovation creation and adoption among SMEs. Reconnoitering innovation among SMEs with two different but connected activities will possibly help researchers to fully discover the innovation process of the SMEs and the role of different firm and owner-manager level factors enabling innovation in SMEs.

\section{References}

Abdu, M., \& Jibir, A. (2018). Determinants of firm's innovation in Nigeria. Kasetsart Journal of Social Sciences, 39(3), 448-456.

AbuJarad, I. Y., \& Yusof, N. (2010). Innovation creation and innovation adoption: A proposed matrix towards a better understanding. International Journal of Organizational Innovation, 3(1), 303-325.

Akinwale, Y. O., Adepoju, A. O., \& Olomu, M. O. (2017). The impact of technological innovation on SME's profitability in Nigeria. International Journal of Research, Innovation and Commercialisation, 1(1), 74-92.

Aminu, I. M., \& Shariff, M. N. M. (2015). Determinants of SMEs performance in Nigeria: A pilot study. Mediterranean Journal of Social Sciences, 6(1), 156.

Anderson, N., De Dreu, C. K., \& Nijstad, B. A. (2004). The routinisation of innovation research: A constructively critical review of the state-of-the-science. Journal of organisational Behavior, 25(2), 147-173.

Anderson, N., Potočnik, K., \& Zhou, J. (2014). Innovation and creativity in organisations: A state-of-the-science review, prospective commentary, and guiding framework. Journal of Management, 40(5), 1297-1333.

Antonioli, D., \& Della Torre, E. (2015). Innovation adoption and training activities in SMEs. The International Journal of Human Resource Management, 27(3), 311-337.

Ayranci, E., \& Semercioz, F. (2011). The relationship between spiritual leadership and issues of spirituality and religiosity: A study of top Turkish managers. International journal of business and management, 6(4), 136.

Baregheh, A., Rowley, J., \& Sambrook, S. (2009). Towards a multidisciplinary definition of innovation. Management decision, 47(8), 1323-1339.

Beckett, R. C., \& Chapman, R. L. (2014, December). What Business Model Constructs Drive Innovation in Australian Manufacturing SMEs. In 28th ANZAM Conference Reshaping Management for Impact, the University of Technology, Sydney (pp. 3-5).

Beyer, M., Czarnitzki, D., \& Kraft, K. (2012). Managerial ownership, entrenchment, and innovation. Economics of Innovation and New Technology, 21(7), 679-699.

Bhaskaran, S. (2006). Incremental innovation and business performance: small and mediumsized food enterprises in a concentrated industry environment. Journal of Small Business Management, 44(1), 64-80.

Bigliardi, B. (2013). The effect of innovation on financial performance: A research study involving SMEs. Innovation, 15(2), 245-255. 
Blanchard, K. (2017). Rural and remote SMEs' innovative behaviour: Is it in the genes or location? An examination of entrepreneurial traits and characteristics. Strategic Change, 26(4), 301-309.

Boyer, T., \& Blazy, R. (2014). Born to be alive? The survival of innovative and non-innovative French micro-start-ups. Small Business Economics, 42(4), 669-683.

Bucktowar, R., Kocak, A., \& Padachi, K. (2015). Entrepreneurial orientation, market orientation, and networking: impact on innovation and firm performance. Journal of Developmental Entrepreneurship, 20(04), 1550024.

Custódio, C., Ferreira, M. A., \& Matos, P. (2017). Do general managerial skills spur innovation? Management Science, 65(2), 459-476.

Daksa, M. D., Yismaw, M. A., Lemessa, S. D., \& Hundie, S. K. (2018). Enterprise innovation in developing countries: an evidence from Ethiopia. Journal of Innovation and Entrepreneurship, 7(1), 6.

Damanpour, F., \& Wischnevsky, J. D. (2006). Research on innovation in organisations: Distinguishing innovation-generating from innovation-adopting organisations. Journal of engineering and technology management, 23(4), 269-291.

Dansoh, A., Oteng, D., \& Frimpong, S. (2017). Innovation development and adoption in small construction firms in Ghana. Construction Innovation, 17(4), 511-535.

Escribá-Esteve, A., \& Montoro-Sánchez, Á. (2012). Guest editorial: Creativity and innovation in the firm: Managerial antecedents and effects on employees. International Journal of Manpower, 33(4), 344-348.

Fagerberg, J., \& Srholec, M. (2008). National innovation systems, capabilities, and economic development. Research Policy, 37(9), 1417-1435.

Farace, S., \& Mazzotta, F. (2015). The effect of human capital and networks on knowledge and innovation in SMEs. Journal of Innovation Economics Management, (1), 39-71.

Fitjar, R. D., \& Rodríguez-Pose, A. (2013). Firm collaboration and modes of innovation in Norway. Research Policy, 42(1), 128-138.

Hosseini, S. M. P., \& Narayanan, S. (2014). Adoption, adaptive innovation, and creative innovation among SMEs in Malaysian manufacturing. Asian Economic Papers, 13(2), 32-58.

Hu, M. L. M., Horng, J. S., \& Sun, Y. H. C. (2009). Hospitality teams: Knowledge sharing and service innovation performance. Tourism Management, 30(1), 41-50.

Kamal, E. M., Yusof, N. A., \& Iranmanesh, M. (2016). Innovation creation, innovation adoption, and firm characteristics in the construction industry. Journal of Science \& Technology Policy Management, 7(1), 43-57.

Laguir, I., \& Den Besten, M. (2016). The influence of an entrepreneur's characteristics on MSEs growth through innovation. Applied Economics, 48(44), 4183-4200.

Lai, K. S., Yusof, N. A., \& Kamal, E. M. (2016). Innovation orientation in architectural firms. Construction Innovation, 16(4), 425-445.

Magadley, W., \& Birdi, K. (2012). Two sides of the innovation coin? An empirical investigation of the relative correlates of idea generation and idea implementation. International Journal of Innovation Management, 16(01), 1250002-1.

Martínez-Román, J. A., \& Romero, I. (2017). Determinants of innovativeness in SMEs: disentangling core innovation and technology adoption capabilities. Review of Managerial Science, 11(3), 543-569. 
Martínez-Ros, E., \& Orfila-Sintes, F. (2012). Training plans, manager's characteristics, and innovation in the accommodation industry. International Journal of Hospitality Management, 31(3), 686-694.

Mateu, J. M., \& March-Chorda, I. (2016). Is experience a useful resource for business model innovation? Technology Analysis \& Strategic Management, 28(10), 1195-1209.

Mohammed, A., \& Abimiku, J. (2015). Innovation among Small and Medium Enterprises in Nigeria. Journal of Resourcefulness and Distinction, 11(1). 1-13.

Mütterlein, J., \& Kunz, R. E. (2017). Innovate alone or with others? Influence of entrepreneurial orientation and alliance orientation on media business model innovation. Journal of Media Business Studies, 14(3), 173-187.

Naranjo-Valencia, J. C., Jiménez-Jiménez, D., \& Sanz-Valle, R. (2011). Innovation or imitation? The role of organizational culture. Management Decision, 49(1), 55-72.

Nguyen, A. N., Pham, N. Q., Nguyen, C. D., \& Nguyen, N. D. (2008). Innovation and exports in Vietnam's SME sector. The European Journal of Development Research, 20(2), 262280.

OECD, 2005. Oslo Manual-Guidelines for Collecting and Interpreting Innovation Data, Paris.

Olughor, R. J. (2015). Effect of innovation on the performance of SMEs organisations in Nigeria. Management, 5(3), 90-95.

Pérez-Luño, A., Wiklund, J., \& Cabrera, R. V. (2011). The dual nature of innovative activity: How entrepreneurial orientation influences innovation generation and adoption. Journal of Business Venturing, 26(5), 555-571.

Quazi, A., \& Talukder, M. (2011). Demographic determinants of adoption of technological innovation. Journal of Computer Information Systems, 52(1), 34-42.

Rietzchel, E. F., \& Zacher, H. (2015). Workplace creativity, innovation, and age. Encyclopedia of geropsychology, 1-8.

Robson, P. J., Haugh, H. M., \& Obeng, B. A. (2009). Entrepreneurship and innovation in Ghana: enterprising Africa. Small Business Economics, 32(3), 331-350.

Rogers, E. M. (2004). A prospective and retrospective look at the diffusion model. Journal of health communication, 9(S1), 13-19.

Rogers, M., \& Rogers, M. (1998). The definition and measurement of innovation.

Ruiz-Jiménez, J. M., \& del Mar Fuentes-Fuentes, M. (2016). Management capabilities, innovation, and gender diversity in the top management team: An empirical analysis in technology-based SMEs. BRQ Business Research Quarterly, 19(2), 107-121.

Subrahmanya, M. B. (2015). Innovation and growth of engineering SMEs in Bangalore: why do only some innovate and only some grow faster? Journal of Engineering and Technology Management, 36, 24-40.

Sundbo, J. (1995). Three paradigms in innovation theory. Science and Public Policy, 22(6), 399-410.

Wadhwa, P., McCormick, M., \& Musteen, M. (2017). Technological innovation among internationality active SMEs in the Czech economy: Role of human and social capital of CEO. European Business Review, 29(2), 164-180.

Wolfe, R. A. (1994). Organisational innovation: Review, critique, and suggested research directions. Journal of management studies, 31(3), 405-431.

Yeşil, S., \& Doğan, I. F. (2019). Exploring the relationship between social capital, innovation capability, and innovation. Innovation, 1-27. 
Yusof, N. A., \& Abidin, N. Z. (2011). Does organisational culture influence the innovativeness of public-listed housing developers? American Journal of Applied Sciences, 8(7), 724.

Yusof, N. A., Lai, K. S., \& Mustafa Kamal, E. (2017). Characteristics of innovation orientations in construction companies. Journal of Engineering, Design, and Technology, 15(4), 436-455. 